EGU21-12286, updated on 01 Feb 2022

https://doi.org/10.5194/egusphere-egu21-12286

EGU General Assembly 2021

(c) Author(s) 2022. This work is distributed under

the Creative Commons Attribution 4.0 License.

\title{
Short-term evolution of submarine canyon head morphologies in the NW Mediterranean: Blanes and Cap de Creus canyons
}

\author{
Cecilia Cabrera ${ }^{1}$, Ruth Durán ${ }^{1,2}$, Pere Puig ${ }^{1}$, Jorge Guillén ${ }^{1}$, Araceli Muñoz ${ }^{3}$, Montse Demestre ${ }^{1}$, and \\ Albert Palanques ${ }^{1}$ \\ ${ }^{1}$ Marine Sciences Institute, CSIC, Barcelona, Spain (ccabrera@icm.csic.es) \\ ${ }^{2}$ University of Malta, Msida, Malta \\ ${ }^{3}$ Tragsa $S$ SP, Madrid, Spain
}

Submarine canyons are morphological features found along continental margins that play a key role channeling and connecting sediment from continental shelves to the abyssal plains. The current morphological characterization of the Blanes and Cap de Creus canyon heads, located on the Catalan continental margin (NW Mediterranean Sea), has been recently conducted during the CRIMA cruise in September 2020 using high-resolution (4 m grid size) multibeam bathymetry data. These data have been compared with a previous dataset collected in 2004 during the ESPACE project to evaluate the morphological changes during this 16-year interval. Since these canyon heads are located at shallow water depths and at short distances from the shoreline, their shortterm evolution is related to the sediment dynamics on the continental shelf.

A large-scale change in the seafloor morphology was observed in the Blanes canyon head, indicating the prevalence of erosion in the western canyon rim and non-deposition in the eastern rim. In the Cap de Creus canyon head, the excavation of pre-existing erosive structures was also evidenced in the southwestern canyon rim. These changes mainly happen in the area where the shelf is narrower, which coincide with the main zone of dense water advection along the shelf and toward the canyon interior. The different small-scale morphological evolution between both canyon heads seems to be related to the local geological characteristic of the subsurface deposits of the continental shelf. The Blanes canyon head incises a succession of relict (Holocene) sediment bodies that can act as a source of erodible sediments to the canyon, mainly during strong storms. The continental shelf in the vicinity of the Cap de Creus canyon head, however, is characterized by a rocky substratum (Paleozoic) with a limited sediment coverage and numerous erosive features that evidence relative sand starvation. This creates a greater erosive resistance, although the erosive character of strong storms and major dense-shelf water cascading events occurring during the studied time interval is evident. Additionally, small changes in the shelf bedforms indicate that such high-energetic oceanographic processes also modify the fine-scale seafloor morphology.

These results reveal that both submarine canyon heads are dynamic and sensitive to oceanographic processes that enhance the erosion and transport of sediment from the shelf into the canyon, particularly during energetic storms and dense shelf water cascading events. 
Nevertheless, their small-scale evolution seems to be closely related to the type of geological substrate of the shelf on which they are developing.

This study has received funding from the ABRIC (RTI2018-096434-B-I00) and CRIMA (RTI2018-095770-B-I00) Spanish Research Projects, the European Union's Horizon 2020 research and innovation programme under Marie Sklodowska-Curie grant agreement No. 867471 and the Generalitat de Catalunya (2017 SGR-663 and -1588). This work is contributing to the ICM's 'Center of Excellence' Severo Ochoa (CEX2019-000928-S). The authors thank the Secretaría General de Pesca and Tragsa for the 2004 ESPACE Project dataset. 